\title{
A Review on Impacts of Climatic Variability on Arabica Coffee Improvement in Ethiopia
}

\author{
Masresha Yirga Haile ${ }^{1,2}$ \\ ${ }^{1}$ Jimma Agricultural Research Center, P.O. Box, 192, Jimma, Ethiopia \\ ${ }^{2}$ Jimma University, College of Agriculture and Veterinary Medicine, P.O.Box, 307, Jimma, Ethiopia \\ *Corresponding Author: Masresha Yirga Haile, Jimma Agricultural Research Center, P.O. Box, 192, \\ Jimma, Ethiopia
}

\begin{abstract}
The direct and indirect effect of climatic variability is one factor responsible for the oscillations and frustrations of the Coffee improvement in Ethiopia. The relationships between the climatic parameters and the agricultural production are quite complex, because environmental factors affect the growth and the development of the plants under different forms during the growth stages of the coffee crop. Over the last decades, the temperature in Ethiopia increased at about $0.2^{\circ} \mathrm{C}$ per decade, while the spatial and temporal variability of precipitation is high. Such rising temperature and erratic rain fall are threatening sustainable coffee production in Ethiopian by enabling outbreak of infection diseases (coffee leaf rust) and infestations of insect pests(coffee berry borer) that decrease the quality and yield of coffee. Hence different mitigation options are an absolute necessity, such as awareness of farmers about resultant treats of climate change, information on change in the biology of the pathogen and insect pests, shade tree planting and collaborative scientific research during development of stress resistance/tolerance variety with support of new molecular tools may help to reduce the vulnerability of Ethiopian coffee economy to continued changes in climate.
\end{abstract}

Keywords: Coffee Arabica, climatic variability, coffee leaf rust, coffee berry borer

\section{INTRODUCTION}

The issue of climate variability has become more threatening not only to food security and sustainable development of any nation, but also to the totality of human existence. About $66 \%$ of the total areas of Ethiopia fall within arid and semi arid climatic zone of the country (MoARD, 1998) which is characterized by high rainfall variability and unpredictability, strong winds, high temperature and high evapo-transpiration (Mamo, 2005). Agriculture in Ethiopian is the driver of the country's economy which accounts for half of Gross Domestic Product and 80\% of employment (MoA, 2007). This means, the dependence of country on agriculture makes its economy extremely vulnerable to the risks associated with climate variability. Recent scientific evidence suggests that the frequency and severity of climatic extremes is increasing. The seasonal climate variability of Ethiopia, particularly rainfall, is influenced by weather systems of various scales; from meso-scales, to the large scale, mainly El Nino-Southern Oscillation (ENSO) related phenomena (NMSA, 1996). The expected increases in the inter-annual variability of precipitation in combination with the warming temperature will likely lead to increases in the occurrence of droughts (Figure 2). The projected higher temperature and variable precipitation levels will unequivocally depress crop yields like coffee through direct effects as well as indirect impact by triggering insect pests and diseases (Gadgil et al., 1998).

Therefore, Climate variability is a serious concern for coffee economy in Ethiopia. Rising temperatures and erratic rain fall are threatening sustainable coffee production in Ethiopian by enabling outbreak of diseases and infestations of insect pests that decrease the quality and yield of coffee berries (Techno serve, 2011). It is, therefore, essential to assess the effect of climate change on crop diseases and insect pest dynamics over an area so as to quantify its effects especially on diseases out break and damage that could be translated into the best adaptation and mitigation options according to the development potential and specific challenges under a specific crops and economically important diseases and insect pests. Therefore, this paper is prepared to assess the direct 
and indirect potential effect of climate change on Arabica coffee improvement in Ethiopia and its possible adaptation and mitigation options.

\section{LiTERATURE REVIEW}

\subsection{Production and Contribution of Coffee in Ethiopian Economy}

Coffea Arabica and Coffea canephora are the most important species in worldwide coffee industry (Davis et al., 2012). However, about 70 percent of the production comes from Arabica coffee. Ethiopian is the first coffee-producing African country (39\%) and stands fifth in the world (5\%) coffee production (ICO, 2014). Coffee contributes about 24 percent of the country's foreign currency earnings (Minten et al., 2014). Ethiopian Coffee cultivation plays a vital role in both the cultural and socio-economic life of the nation. Hence, more than 15 million populations depend on coffee value chain for their income and employment (Gray et al., 2013).

The crop is mainly produced in the Southern, South western and Eastern parts of the country. In general, it is estimated that there is a potential of 900,000 hectares of cultivable land suitable for coffee production. The estimated annual national production is about 500,000-700,000 tones, of which about $95 \%$ is produced by four million small scale-farmers with average landholdings below two ha and earning less than a dollar per day (Berhanu et al., 2015). More than fifty percent of its production has been locally consumed, reflecting the commodity's cultural importance in the country (USAID, 2012; Berhanu et al., 2015). Although, the level of area cultivated continued to increase, the volume of coffee produced decrease. An explanation could be the adverse climate condition that damaged the crops (Promar, 2011), outbreak of diseases and infestations of insect pests, lack of proper extension services, and limited number of improved variety.

The four major types of commercial coffee are Jimma, Sidama, Yirgacheffe, and Harar. The names correspond to the cities around which they are produced. These four coffee trademarks represent around 70 percent of total coffee exports registered by the Ethiopian Revenue and Customs Authority (Arslan and Reicher, 2011). Ethiopia's main trading partners are Germany (29\%), Saudi Arabia (15\%) and Japan (16\%). Exports to the United States are also on the rise, their share of total exports increasing from 4 percent to 8 percent between 2000 and 2011 (FAO, 2014).

\subsection{Coffee Production Systems in Ethiopia}

Ethiopian coffee is cultivated under forest, semi-forest, garden and plantation systems with their intensification gradient (Kufa, 2012). Forest coffee counted for 10 percent of total coffee production in which Planting is done with self sown or spontaneous seedlings with no or very limited management efforts (Hundera et al., 2013b). Semi-forest coffee (35\%) is produced in relatively disturbed natural forests where the upper canopy is tinned and coffee is sometimes randomly planted in the forest to increase the number of shrubs and coffee yields with slashing once a year (Gole et al., 2008). Garden coffee $(50 \%)$ is planted on small-scale agricultural plots either in monoculture with scattered shade trees or intercropped with fruit, spices, and false banana. Plantation coffee $(5 \%)$ is large-scale coffee farm established by larger private investors with modern production systems (Van der Graaff, 1981). Coffee yields increase along this intensification gradient. Coffee produced by small-scale farmers typically yields 500 to $600 \mathrm{~kg}$ per hectare, while commercial plantations and state farms can yield up to $1200 \mathrm{~kg}$ per hectare (Beshah et al.,, 2013).

\subsection{Genetic Diversity of Coffea Arabica as a Valuable Basis for Breeding}

Ethiopia is not only the major producer and exporter of Arabica coffee, but also origin and center of genetic diversity for this valuable crop species. The largest and most diverse populations of indigenous (wild) Arabica occur in the highlands of southwestern Ethiopia (TeketayD., 1999; Gole TW., 2003; Labouisse et al., 2008); While It's cultivated form is grown throughout Africa and South America (Koebler, 2013). The genetic diversity of wild Arabica populations far exceeds that of cultivated varieties used in crop production and accessions held in germplasm collections (Labouisse et al., 2008). However, the cultivated, commercial form of Arabica coffee lacks genetic diversity, which makes it especially prone to diseases (Paramaguru, 2012). Different research findings illustrate the importance of the Ethiopian coffee genetic materials in breeding programs for high productivity and disease resistance (Bertrand et al., 1997; Labouisse et al., 2008; Adugna G, 2005; Anzueto et al., 2001). Ethiopian $C$. Arabica materials were used as parents and crossed with commercial varieties to 
obtain strong hybrid vigor, resulting in over $30 \%$ higher productivity of the F1 hybrids in Central America (Bertrand et al., 1997).

The other evidence in the existence of genetic diversity in coffee in Ethiopia is the damage caused to coffee production in Eastern Africa by the outbreak of the coffee berry disease in the 1970s and 1980s. In Ethiopia, the disease does not affect coffee production significantly, chiefly due to the availability of high genetic diversity, which helped to develop cultivars resistant to the disease in a very short time using materials from the wild coffee gene pool (Mesfin and Bayetta, 1984). Moreover, the diversity of coffee, soil and climate, production and processing methods, among others enabled the country to produce and supply the de facto organic coffees (Taye and Tesfaye, 2002).

The wild populations also have high functional diversity in terms of disease (Adugna G, 2005), and pest and drought tolerance (Taye K, 2006). As part of a future-proofing resource, and especially for providing genetic potential for mitigating climate change, indigenous populations are perceived as a key resource for the medium- to long-term sustainability of Arabica production (Hein L. and Gatzweiler F, 2006).

\subsection{Ecological Requirements of Coffee Arabica}

For optimum growth and taste, Arabica coffee needs to be in an environment of about 15 to 25 degree Celsius, Rainfall is well distributed, varying from 1,600 to more than 2,000 mm, with a dry season lasting three to four months coinciding with the coolest period and at altitudes ranging from 1, 500 to $2,800 \mathrm{~m}$, between the latitudes of $4^{\circ} \mathrm{N}$ and $9^{\circ} \mathrm{N}$. Being exposed to temperatures of about 23 degrees or higher can cause the coffee plants to ripen, which negatively affects the taste and quality. Arabica coffee is a unique species because of its climate sensitivity (Davis et al., 2012).

Continuous exposure to temperatures as high as $30^{\circ} \mathrm{C}$ leads to stress, which is manifest as depressed growth and abnormalities, such as the yellowing of leaves and growth of tumors on the stem (Franco CM., 1958). In regions with a mean annual temperature below $17-18^{\circ} \mathrm{C}$ growth is also depressed (DaMatta FM, Ramalho JDC., 2006). Occurrence of frosts, even if sporadic, may strongly limit the economic success of the crop (Camargo AP., 1985). The relationships between climatic parameters and agricultural production is further complicated because these environmental factors influence the growth and the development of the plants in different ways during the various growth stages of the coffee (Camargo MBP, 2010).

\subsection{Consequential Risks of Climate Change to Coffee}

Arabica coffee has picky temperature requirements; hence climate change could lead to disastrous impacts on the worldwide coffee industry. Jaramillo et al (2009) stated that even the smallest increases in temperature could cause extensive damage to coffee production. They estimate that if climate change continues on its current trend, the suitable land for growing coffee could face a reduction by up to 95 percent. Between the years 2009 and 2011, the prices of Arabica coffee increased by 160 percent; while Productivity decreased in most coffee growing areas in the tropics like in East Africa and Latin America, which face severe threats of extreme climate change (Jaramillo et al., 2011).

Moreover, Davis et al. (2012) published their research on the effect of climate change on the Indigenous Coffee Arabica plant on the 349 localities. Their research proved that the plant's growing success is directly linked to accelerated climate change, but there is a profoundly negative trend in this relationship. At best, they predict there will be a 65 percent decrease in Arabica production by the year 2080. At worst, they say there will be a 100 percent decrease by 2080 . Arabica coffee is confirmed as a climate sensitivity species, supporting data and inference that existing plantations will be negatively impacted by climate change. Ethiopia, which is the main African coffee producer, will face serious consequences since coffee exports account for about 24 percent of Ethiopia's export revenue. Ramirez-Villegas et al. (2012) say that to protect coffee and coffee prices, greenhouse gases must be limited and reduced. Possible ways to limit greenhouse gases include a reduction in deforestation and better crop management (Ramirez-Villegas et al., 2012).

\subsection{Loss of Genetic Diversity and Conservation Strategy}

Despite of its importance as invaluable genetic resource nationally and internationally for current as well as future crop improvement work, the Ethiopian Arabica coffee gene pool is threatened of 
genetic erosion mostly attributable to deforestation of its natural habitat for timber and food crop production, replacement of the farmer's variety by a few high yielding, establishment and expansion of modern plantation and illegal and legal settlements (Woldemariam et al., 2002).

To mitigate such threats starting from 1973 a total of about 11691 Arabica coffee germplasm accessions that have been collected and ex-situ conserved at the Jimma Agricultural Research Centers (5960 accessions) and Institute of Biodiversity Conservation (5731 accessions) field gene banks ( Kufa, 2010). However, some germplasm like harari collection have been died from their maintained field due to climate change and adaptation problem as they are forced to be grown outside their original environment. It has been well understood that varieties belonging to one region adapt differently when grown in another region (Bayetta et al., 1993).To alleviate such barrier, the conservation program was designed to conserve the germplasm collections according to their area of origin and specific adaptation to minimize the risk of genetic erosion (Fikadu et al., 2008). Accordingly, to date Jimma agricultural Research Center has developed and released 40 new coffee cultivars (34 pure lines and 6 hybrids) for different localities but some of released varieties like 741 become low yielder and susceptible to new break of disease. Between 1960 and 2006 the average temperature of the country rose by $1.3^{\circ} \mathrm{C}$, fluctuations in the seasonal and annual rainfall became bigger, and coffee harvests declined. Some coffee producers shifted their plantings to higher areas, while others were forced to stop growing coffee and switch to livestock and heat-tolerant crops such as ensete (a starchy root crop). Additionally, the death of coffee seedling has been increasing in the research plot and on the farmer's field during establishment in Ethiopian (Jarc, 2015).

\subsection{Impacts of Drought and Temperature Stress on Coffee Physiology}

The climatic variability becomes the main factor responsible for the oscillations and frustrations of the coffee yield in Ethiopia. The relationships between the climatic parameters and the agricultural production are quite complex, because environmental factors affect the growth and the development of the plants under different forms during the phenological phases of the coffee crop (Camargo, 2001).

High temperatures are known to disturb plant metabolism. Coffee cultivation in the open is the usual provokes leaf exposure to high irradiance and the absorption of much more energy than that usable by photosynthesis. Such conditions may cause an energy overcharge and to an overheating of leaves that occurs on sunny days in un-shaded crops (Maestri et al., 2001). The processes of photosynthesis become limited when water stress occurs, due to closing of the stoma and reduction in other physiological activities in the plant. The physiological mechanisms underlying coffee tolerance to drought appear to be largely related to the strong sensitivity of coffee stomata to both soil and atmospheric (Pinheiro et al., 2005) this suggests a strong sensitivity of coffee stomata to rising internal water deficit.

Other climatic factors can reduce the productivity, such as adverse air temperatures happened during different growth stages. The increase of greenhouse gas emissions (GHG) in the atmosphere is causing wide changes in atmospheric events, influencing climate change and variability with critical impacts on vegetations (Marengo, 2007). A quality problem could arise, from the faster plant growth that will lead to lower coffee fruit quality. Besides, high maximum temperatures during summer months may cause an excessive fruit ripening, against fruit quality. The extreme conditions can be responsible of physiological stresses, such as the reduction of photosynthetic efficiency. Others critical phases are flowering and grain fill in relation with the anticipation of bud dormancy break. Moreover high temperature and dry conditions during the reproductive phase can be critical for the optimum coffee production and quality (Camargo and Camargo, 2001).

\subsection{Coffee Leaf Rust (Hemileia Vastatrix)}

Climate change in South America and East Africa has had many negative effects on agriculture, specifically coffee production. One unexpected result from climate change is the increase in predators for coffee plants. Coffee leaf rust (CLR) is a fungus that has emerged as a result of climate change. CLR is originated in Africa and Asia, but it now can be found in almost all coffee-producing regions due to dispersal of viable spores through wind (Koebler, 2013). In the 1860s, coffee leaf rust lead to the destruction of the entire population of coffee in Sri Lanka (Koebler, 2013). Arabica coffee does not have many natural predators and the most susceptible species to Leaf rust. Warming temperatures 
at higher altitudes and the resulting shifts in moisture accumulation are likely allowing the rust to thrive in areas previously uninhabitable (Avelino et al. 2006). Despite the availability of effective fungicides and resistant varieties for the control of CLR, it may still cause losses varying between 10 and $40 \%$ in different countries (Silva et al., 2006) because fungicides can be detrimental to the environment and are limited in capacity to combat coffee rust and some improved commercial varieties gradually losing their resistance to leaf rust in some countries, due to the appearance of new virulent races (Rodrigues et al., 2000).

CLR was first reported in Ethiopia in 1934 (Sylvain PG., 1958), but the disease had existed for a long time without causing epidemics. The possible reason might be due to the long-term coexistence of coffee and rust coupled with the high genetic diversity of coffee populations and a high level of horizontal resistance (Van der Graaff NA., 1981). Other factors such as the low average productivity associated with shade and the existence of biological agents such as the hyper parasite Verticillium lecanii, were also believed to play an important role in maintaining CLR at low levels. Farmers learned that moving to cooler regions at higher elevations could eliminate the presence of this fungus. However, the increasing temperatures and rainfall resulting from climate change has led to coffee leaf rust becoming prevalent at higher altitudes (Koebler, 2013).

\subsection{Biology of the Pathogen}

The Coffee Rust is an obligate parasitic fungus, which means it is a microorganism that must take energy and nutrients from a specific live host (coffee) and reproduces differently than either plants or animals. It belongs to the family of Pucciniaceae in the order of Uredinales of the class Basidiomycetes (Mayne WW., 1932). The pathogen prefers a temperature range of $20-28{ }^{\circ} \mathrm{C}$ needs a leaf wetness period only during spore germination and penetrates with the germination hyphae into the stomata of the host. The fungus tolerates longer seasons without rainfall and spores are windborne, only attacking leaves and needs no other host for completing the life cycle.

Due to the fact that coffee is a perennial host with green leaves all through the year, the pathogen produces the uredinal, telial, and basidial stages, but only the dycariotic urediospores are responsible for the disease. Typically, a single spot of rust on a leaf can produce 4-6 generations of spores over a 3-5 month period. This could result in the release of hundreds of thousands of individual mature spores; ready to start the process all over again. Coffee grown in lower altitudes is more predisposed to the disease and suffers more attacks. When a coffee plant does not have the optimal amount of leaf area, it does not have the ability to accumulate adequate energy via photosynthesis and store up the appropriate resources for fruit production. This is why there is generally a loss of yield even the year after rust outbreaks (Avelino and others 2004).

\subsection{Occurrence of Coffee Leaf Rust in Ethiopia}

Chala et al (2010) suggested that the CLR assessments in the rainforests of Ethiopia revealed its presence in all fields differing in incidence with time (season) and location. For instance, in 2008, A significantly high rust incidence was recorded at Yayu (31.1\%) followed by Berhane-Kontir (21.4\%) and Bonga (7.9\%) forest coffee populations. Higher rust incidences were found in January (29.6\%) and April (22.7\%), while lower incidences were observed in July (13.9\%) and October (14.3\%).

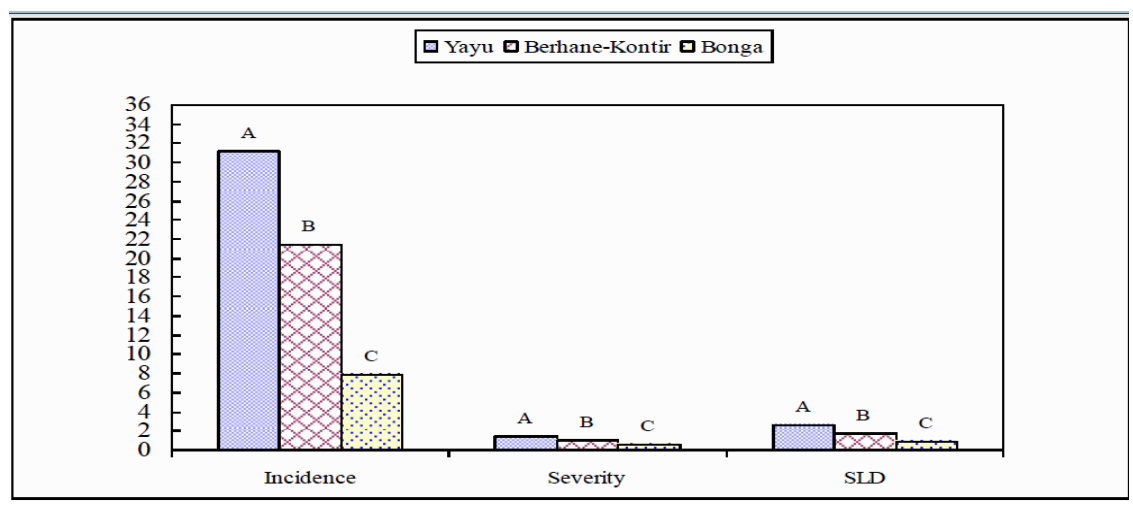

Figure1: Coffee leaf rust incidence (\%), severity (\%) and sporulation lesion density (SLD) in three montane forest coffee populations of southwestern Ethiopia (July 2007-April 2008).Values were mean of four assessments (July 2007, October 2007, January 2008 and April 2008) for each disease parameter at each 
location. Bars with the same letters within each disease parameter are not significantly different according to LSD at $P=0.05$

\subsection{Coffee Berry Borer}

Coffee berry borer (Hypothenemus hampei) is another main threat to coffee pest which has drastically increased in recent years directly resulting from climate change (Jaramillo et al., 2009). H. hampei is one of only a few herbivores that have the ability to detoxify caffeine. Therefore, the insect has no problem feeding on the berries on Arabica coffee plants and remains as the unopposed enemy to coffee (Jaramillo et al., 2009). The coffee berry borer attacks the beans, which are the marketable product, causing losses exceeding US \$500 million annually, and worldwide affects many of the more than 25 million rural households involved in coffee production (Vega FE.et al., 2003). Under low pest pressure the conversion factor (i.e. after processing, the amount of parchment coffee obtained from a given amount of freshly picked coffee berries) is 5:1; however, a serious $H$. hampei infestation can alter this ratio up to $>17: 1$, with devastating economic consequences for farmers ( Baker PS.et La., 2002).

Change has had many negative impacts on nature; the coffee berry borer has thrived with the rise in temperatures. Jaramillo et al. (2009) found that the population growth of $H$. hampei is directly and exponentially related to increases in temperatures. As temperatures rise, generations of the insect multiply. A study performed by Jaramillo et al. (2009) determined that a 1 to 2 degree Celsius increase in temperature would cause the $H$. hampei to develop faster; this would lead to more generations per fruiting season. They found that increases of over 2 degrees Celsius would force the $H$. hampei to migrate to higher altitudes. This explains the bugs' shift from lower elevation where Coffea canephora grows to the higher altitudes of Coffea Arabica.

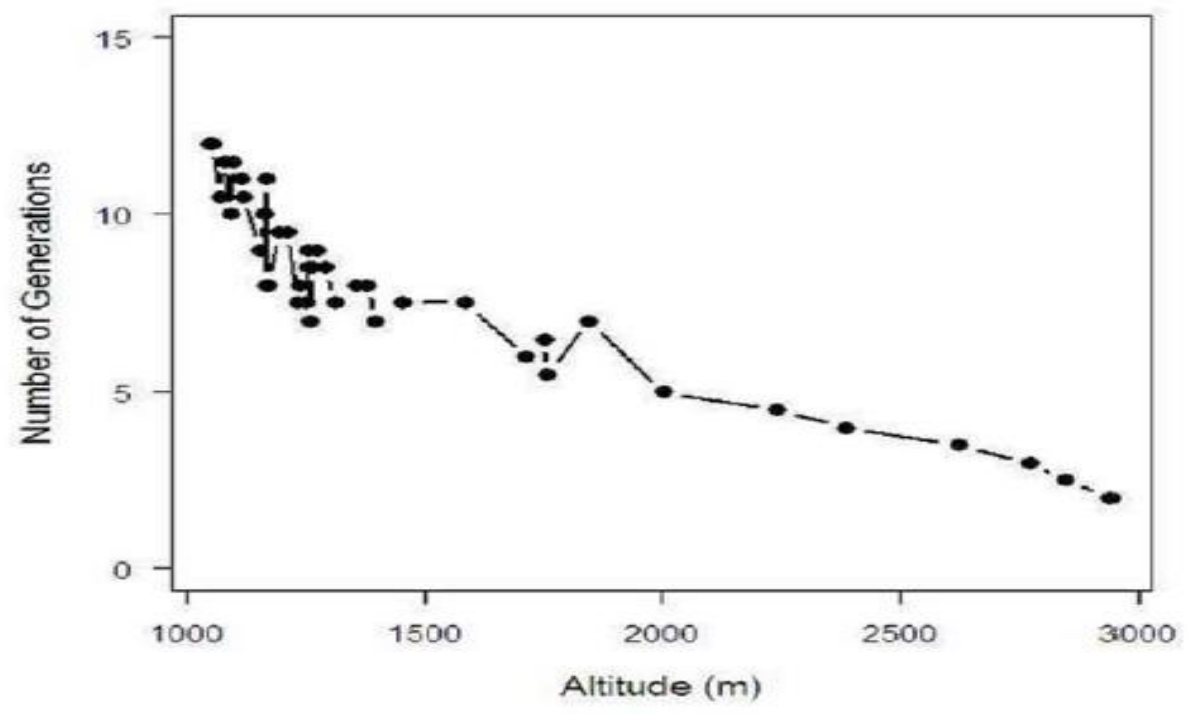

Figure2. Number of coffee berry borer (Hypothenemus hampei) generations per year along an altitudinal transect around Lake Victoria (Tanzania, Uganda and Kenya) under current climate and according to the HadCM3-SRES A2 and B2 scenarios in 2050. doi:10.1371/journal.pone.0024528.g009

Two years later, Jaramillo et al. (2011) looked back at their predictions. They found that their predictions were holding true. Over the coming years, they predict the climate of southwest Ethiopia will become more suitable for the coffee berry borer. Southwest Ethiopia is the main location of Arabica coffee production in Africa. Another prediction about the future of the coffee berry borer claims that the population increases will become drastic. Currently, about 1 to 4 generations are born each fruiting season, which refers to the time of year when Arabica coffee thrives (Jaramillo et al., 2011). At best, Jaramillo et al. (2011) predict this will increase to somewhere between 5 and 10 generations per fruiting season. At worst, they say the numbers could increase from 10 to 16 generations. This drastic increase in the population of coffee's main insect predator will not help the already struggling coffee industry.

Jaramillo et al. (2009) calculate that Colombia will experience a devastating impact because of its precipitation. Colombia experiences yearlong precipitation and climate change is expected to increase this. This leads to more flowerings of Arabica coffee, thus creating more food for H. hampei. Ethiopia 
will face problems as well, but not as much as Colombia because Ethiopia's dry season will limit the flowerings per year (Jaramillo et al., 2009). Jaramillo et al. (2011) explain that the exact origin of the H. hampei is unknown. The bugs first came to Colombia in 1988 (Jaramillo et al., 2009). In Africa, research shows the insect probably originated as a predator to Coffea canephora, a lesser-used coffee plant that grows at lower altitudes and warmer temperatures than Coffea Arabica (Jaramillo et al., 2011), a species naturally occurring and cultivated at lower altitudes (250-1500 m.a.s.l.).

With rising temperatures, the coffee berry borer could be forced to migrate to higher altitudes where Arabica grows, giving it a new diet on which it can thrive. Recently, populations of the coffee berry borer have increased throughout southwestern Ethiopia. Analysis of the climate data collected by the Jimma weather station has shown that, until 1984, temperatures were too low to allow the coffee borer to complete a full generation cycle. The higher temperatures mean the beetle can now complete one to two reproduction cycles per year. If temperatures continue to rise, the reproduction rate may further increase, resulting in even greater harvest losses. Growing the coffee plants under shade trees is currently the most effective way of countering the problem (Oxfam, 2010).

\subsection{Mitigation Options}

\subsubsection{Agronomic Management and Adaptation}

Ethiopia must take several strategies to prevent the damage on coffee production. If no action is taken, coffee production will encounter enormous harm and the economies would greatly suffer due to dependence on coffee exports. In order to limit the risk of biotic and a biotic stress on Arabica coffee, farmers need to monitor their crops more closely; they need to implement some form of an earlywarning system and the governments must increase funding for research that could prevent the extinction of Arabica coffee (Ramirez-Villegas et al., 2012).

In order to fight rising temperatures, several researchers argue that coffee plants should be moved to higher elevations where temperatures are usually a few degrees cooler (Jaramillo et al., 2011; Davis et al, 2012; Ramirez-Villegas et al., 2012). However, re-colonizing Arabica coffee plants in Ethiopia is not necessarily a good idea because it will take many years for the plants to become productive again (Davis et al. (2012). Scientists seem to agree that the best way to preserve Arabica coffee is through the use of shade trees (Jaramillo et al., 2009; Jaramillo et al., 2011; Ramirez-Villegas et al., 2012). Shade trees planted near coffee plants have the ability to block out the sun's impact on the plants. They create lower temperatures better suited for Arabica coffee plants. Jaramillo et al. (2011) say shade trees can cause a reduction in temperature by up to 4 degrees Celsius.

Under tropical conditions, shade is very much essential to prevent over-bearing, suppress weed growth, reduce the intensity of sunlight, and combat drought effects, to maintain the moisture levels in tissues and to protect the coffee plants from low temperature, wind velocities and damage caused by hail stone. Shade limits the incidence of pest such as white stem borer and leaf rust disease in Arabica coffee. The incidence of white stem borer, which can cause death of plants, will be more in Arabica coffee grown under less shaded condition. With the widespread implementation of shade trees in Ethiopia, the increase in the population of $H$. hampei could be about 34 percent lower than expected (Jaramillo et al., 2011). Similarly the incidence of leaf rust will be more in Arabica coffee grown in open condition compared to shaded condition. The shade was also found to improve the coffee quality

\subsubsection{Developing Adaptable Variety}

The main objectives when it comes to genetic manipulation are those of developing higher yields, stress resistance/tolerance, increased quality and strength, and longevity. It is thus essential that genetic improvement based on selective breeding of Arabica a species contributes to the long-term sustainability of coffee cultivation in potentially affected lands. In some cases, research has focused on developing varieties that could cope well with higher temperatures and remain highly productive at the same time currently working on the possibility of transferring the characteristics of Robusta to Arabica coffee, such as resistance to pests, vigor, and higher resistance to higher temperatures. A biotic stress tolerance like drought is mainly controlled by many genes. Study of numerous physiological and biochemical traits as well as study of developmental, morphological and ultrastructural traits lead to the concept of pyramiding physiological traits (Yeo et al., 1990). Therefore, for rapid and effective screening of a biotic stress resistance/tolerance variety physiologists and breeders should work in collaboration (Blum et al., 1994). 


\section{CONCLUSION}

Despite coffee plays dominant role in social, cultural and national economy of Ethiopia, the country's coffee industry is potentially at risk due to the negative impact of climate change on suitability of coffee production areas with change in diseases and insect pest pattern. Therefore, there is a need to investigate further information and researches on change in biology pathogen and insect pest, resistant ability of previously released commercial cultivars, coffee farming systems and their influences on coffee disease prevalence, awareness of farmers about climate change and other related issues. Moreover, fundamental and collaborative scientific research using different coffee crop management, genetic breeding and new molecular tools focusing on this subject should be highly recommended. Under agronomical aspects some strategies may have on global warming in coffee crop that can reduce the impact of unfavorable temperatures, such as shading management system, planting at high densities, vegetated soil, correct irrigation and agronomical adaptation with focus on breeding programs. Generally, the frequency and severity of climatic extremes are increasing and making adaptation is an absolute necessity and in the long run to reduce the vulnerability of Ethiopian coffee economy, breeders should work in collaboration with other disciples for a rapid and effective screening of a biotic stress resistance/tolerance variety development.

\section{REFERENCES}

[1] Adugna G, Hindorf H, Steiner U, Nirenberg H, Dehne I, et al. (2005) Genetic diversity in the coffee wilt pathogen (Gibberella xylarioides) populations: differentiation by host specialization and RAPD analysis. J Plant Dis Protect 112: 134-145.

[2] Alemayehu T., Esayas K, and Kassu K., (2008).Coffee Development and Marketing Improvement plan in Ethiopia: Coffee diversity and knowledge Proceedings of National Workshop Four Decades of Coffee Research and Development in Ethiopia. Addis Abeba, Ethiopia, pp. 58-63

[3] Amsalu, A. and Ludi, E. (2010), The Effect of Global Coffee Price Changes on Rural Livelihoods and Natural

[4] Avelino J, Zelaya H, Merlo A, Pineda A, Ordonez M \& Savary S. 2006. The intensity of a coffee rust epidemic Resource Management in Ethiopia: A Case Study from Jimma Area. NCCR North-South Dialogue 26, Bern.

[5] Baker PS, Jackson JAF, Murphy ST (2002) Natural enemies, natural allies. Project completion report of the integrated management of coffee berry borer project, CFC/ICO/02 (1998-2002). The commodities press. CABI commodities. Egham UK and Cenicafé, Chinchiná, Colombia.

[6] Bayetta, B. and J.P. Labouisse, 2006. Arabica coffee (Coffea Arabica L.) local landrace development strategy in its center of origin and diversity. Proceedings of the 20th International Coffee Science Conference, Oct. 11-15, France, pp

[7] Bayetta B, Ashenafi A.and Tadesse Benti. 1993. Screening of Arabica coffee collection for Bebeka environment, p175. In: 15th International scientific colloquium on coffee (Vol.1), 6-11 June 1993, Montpelier, France.

[8] Brohan et al. 2006: Uncertainty estimates in regional and global observed temperature changes: A new data set from 1850. Journal of Geophysical Research Atmospheres, 111, D12106.

[9] Camargo AP (1985) Florescimento e frutificação de café arábica nas diferentes regiões cafeeiras do Brasil. Pesqui Agropecu Bras 20: 831-839

[10] Camargo MBP (2010) the impact of climatic variability and climate change on Arabic coffee crop in Brazil. Bragantia 69: 239-247

[11] Camargo, M.B.P., Rolim, G.S., Santos, M.A. Modelagem agroclimatológica do café: estimativa e mapeamento das produtividades. Informe Agropecuário, v.28, p.58 - 65, 2007.

[12] DaMatta FM, Ramalho JDC (2006) Impacts of drought and temperature stress on coffee physiology and production: a review. Braz J Plant Physiol 18: 55-81

[13] Davis, Aaron P.; Tadesse Woldemariam Gole; Susana Baena; and Justin Moat (2012). The Impact of Climate Change on Indigenous Arabica Coffee (Coffea Arabica): Predicting Future Trends and Identifying Priorities. PLOS ONE, Vol. 7, No. 11, pp. 1-13;

[14] Deressa, Temesgen Tadesse (2007). Measuring the Economic Impact of Climate Change on Ethiopian Agriculture: Ricardian Approach. World Bank Policy Research Working Paper No. 4342.

[15] Eitzinger A, Laderach P, Ovalle O, Ramírez J, Jarvis A (2010) Climate Change Adaptation and Mitigation in the Kenyan Coffee Sector. CIAT - International Center for Tropical Agriculture. Manual.

[16] Fikadu Tefera, Bayetta Bellachew, Behailu Atero, Ashenafi Ayano and Tadesse Benti. 2008. Germplasm collection and maintenance of coffee (Coffee Arabica L In: Girma Adugna, Bayetta Belachew, Tesfaye 
Shimber, Endale Taye and Taye Kufa (Eds.). Coffee Diversity and Knowledge. Proceedings of a National Workshop Four Decades of Coffee Research and Development in Ethiopia, 14-17 August 2007, Addis Ababa, Ethiopia.

[17] Franco CM (1958) Influence of temperature on growth of coffee plant. New York: IBEC Research Institute. $24 \mathrm{p}$.

[18] Gadgil, S., P.R. Seshagiri and S. Sridhar. (1998), Modeling impacts of climate variability on rain fed groundnut. Bangalore, India: Indian Institute of Science. pp: 11.

[19] Gole TW (2003) Vegetation of the Yayu Forest in SW Ethiopia: impacts of human use and implications for in situ conservation of wild Coffea Arabica L. populations. Ph.D. Thesis. University of Bonn, Germany.

[20] Gole, T.W. and Senebeta, F., 2008. Sustainable management and promotion of forest coffee

[21] Hein L, Gatzweiler F (2006) the economic value of coffee (Coffea Arabica) genetic resources. Ecol Econ 60: 176-185 in Bale, Ethiopia. Bale Eco-Region Sustainable Management Program SOS

[22] IPCC, 2007: Climate Change 2007: Synthesis Report. Contribution of Working Groups I, II and III to the Fourth Assessment Report of the Intergovernmental Panel on Climate Change [Core Writing Team, Pachauri, R.K and Reisinger, A. (Eds.)]. IPCC, Geneva, Switzerland, 104 pp.

[23] Jaramillo, Juliana; Adenirin Chabi-Olaye; Charles Kamonjo; Alvaro Jaramillo; Fernando E. Vega; HansMichael Poehling; and Christian Borgemeister (2009). Thermal Tolerance of the Coffee Berry Borer Hypothenemus hampei: Predictions of Climate Change Impact on a Tropical Insect Pest. PLOS ONE, Vol. 4, No. 8, pp. 1-11

[24] Jaramillo, Juliana; Eric Muchugu; Fernando E. Vega; Aaron Davis; Christian Borgemeister; and Adenirin Chabi-Olaye (2011). Some Like It Hot: The Influence and Implications of Climate Change on Coffee Berry Borer (Hypothenemus hampei) and Coffee Production in East Africa. PLOS ONE, Vol. 6, No. 9, pp. 1-14; available at:

[25] Koebler, Jason (2013). Buzzkill? How Climate Change Could Eventually End Coffee. USNews.com, US News \& World Report (27 March 2013); available at:

[26] Labouisse J-P, Bellachew B, Kotecha S, Bertrand B (2008) Current status of coffee (Coffea Arabica L.) genetic resources in Ethiopia: implications for conservation. Genet Resour Crop Ev 55: 1079-1093

[27] MAESTRI, M.; BARROS, R.S.; RENA, A.B. Coffee. In: LAST, F.T. (Ed.). Tree crop ecosystems. 1. ed. Amsterdam: Elsevier Publishers, 2001. p.339-360.

[28] Mamo, G., (2005), Using seasonal climate outlook to advice on sorghum production in the central Rift valley of Ethiopia. PhD Thesis, Blomefontein, Republic of South Africa.

[29] MARENGO, J.A. Cenários de mudanças climáticas para o Brasil em 2100. Ciência \& Ambiente, v.34, p.100-125, 2007.

[30] Mayne WW (1932) Physiologic specialization of Hemileia vastatrix B. ET Br. Nature 129:510.

[31] Mesfin Ameha and Bayetta Belachew (1984), Resistance of the F1 to coffee berry disease in six parent diallel crosses in coffee. In: Proceedings of the first regional workshop on coffee berry disease. 19-23 July 1982, Addis Ababa, Ethiopia. pp 167-177.

[32] MoA (Ministry of Agriculture). (1998), Agro ecological zones of Ethiopia. Ministry of agriculture. Addis Ababa, Ethiopia.

[33] MoARD (Ministry of Agriculture and Rural Development), (2007), Ministry of agriculture and rural development crop development crop variety register. Addis Ababa, Ethiopia, 7: 104.

[34] Muller RA, Berry D, Avelino J \& Bieysse D. 2009. Coffee Diseases. In: Wintgens, N., editor). Coffee: Growing, Processing, Sustainable Production. Wiley-VCH Verlag GmbH \& Co. KGaA. p. 491-545

[35] NMSA (National Meteorology Service Agency) (1996), Climatic and agro-climatic resources of Ethiopia. Meteorological research report series Vol. 1, No. 1. National Meteorology Service Agency of Ethiopia, Addis Ababa. 137 pp

[36] Paramaguru, Kharunya (2012). Coffee Under Threat: How Wild Arabica Could Go Extinct. Time.com. TIME, news story (November 16, 2012);

[37] Paulos, D. and D. Teketay, 2000. The need for forest coffee germplasm conservation in Ethiopia and its significance in the control of coffee diseases. Proceedings of the Workshop on Control of Coffee Berry Disease (CBD) in Ethiopia, Aug. 13-15, Addis Ababa, Ethiopia, pp: 125-135.

[38] Pinheiro HA, DaMatta FM, Chaves ARM, Loureiro ME, Ducatti C (2005) Drought tolerance is associated with rooting depth and stomatal control of water use in clones of Coffea canephora. Ann. Bot. 96:101 108

[39] Ramirez-Villegas, Julian; Mike Salazar; Andy Jarvis; and Carlos E. Navarro-Racines (2012). A Way Forward on Adaptation to Climate Change in Colombian Agriculture: Perspectives towards 2050. Climatic Change, Vol. 115, Nos. 3/4, pp. 611-628 
[40] Rodrigues Jr. CJ, Várzea VMP, Godinho IL, Palma S, Rato RC (1993) New physiologic races of Hemileia vastatrix In: Proceedings of the 15th International Conference on Coffee Science (ASIC), Montpellier, France, pp 318-321.Sahel/FARM-Africa, Addis Ababa. Sahel/FARM-Africa, Addis Ababa.

[41] Schneider et al. 2008: Global precipitation analysis products of the GPCC. Technical report, Global Precipitation Climatology Centre (GPCC), Deutscher Wetterdienst.

[42] Silva, M.C., Varzea, V., Guerra-Guimaraes, L., HAzinheira, G., Fernandez, D., Petitot, A.S., Bertrand, B., Lashermes, P. and Nicole, M. 2006. Coffee resistance to main diseases: Leaf rust and coffee berry disease. Brazilian Journal of Plant Physiology 18(1): 119- 147.

[43] Sylvain PG. Ethiopian coffee - its significance to world coffee problems. Econ Bot 1958; 12(2):111-39.

[44] Taye K (2006) Eco-physiological diversity of wild Arabica populations in Ethiopia: growth, water relations and hydraulic characteristics along a climatic gradient. Ecology and Development Series No. 46. Cuvillier Verlag: Göttingen. 305 p.

[45] Taye K, Tesfaye S (2002). Organic coffee production: hope for small-scale farmers in Ethiopia. pp 12461252. Proceedings of the 19th International Conference on Coffee Science (ASIC), May 14th-18th, 2001, Trieste, Italy.

[46] Taye K and Jurgen,2008.Ecophysiolog of wild coffeaine population in mountane rain forest welgekno of Ethiopia .Proceedings of coffee knowledge and diversity .work shop of EIAR .Addis

[47] Technoserv (2011), Photo: Image Used with Permission from Technoserv.

[48] Teketay D (1999) History, botany and ecological requirements of Coffee. Walia, J Ethiopian Wildlife Nat Hist Soc 20: 28-50

[49] Van der Graaff NA. Selection of Arabica coffee types resistant to coffee berry disease in Ethiopia. Wageningen: Mededelingen Landbouwhogeschool; 1981.

[50] Vega FE, Rosenquist E, Collins W (2003) Global project needed to tackle coffee crisis. Nature 435: 343.

[51] Woldemariam, T., M. Denich, D. Teketay and P.L.G. Vlek, 2002. Human impacts on Coffea Arabica L. Genetic Pools in Ethiopia and the Need for Its in situ Conservation. In: Managing Plant Genetic Diversity, Engels, J.M., M. Rao, V.R. Brown and M.T. Jackson (Eds.). IPGRI Publication,Rome,pp:237

Citation: Y. H. Masresha, "A Review on Impacts of Climatic Variability on Arabica Coffee Improvement in Ethiopia", International Journal of Forestry and Horticulture, vol. 4, no. 1, p. 9-18, 2018. http://dx.doi.org/ 10.20431/2454-9487.0401002

Copyright: (C) 2018 Authors. This is an open-access article distributed under the terms of the Creative Commons Attribution License, which permits unrestricted use, distribution, and reproduction in any medium, provided the original author and source are credited. 